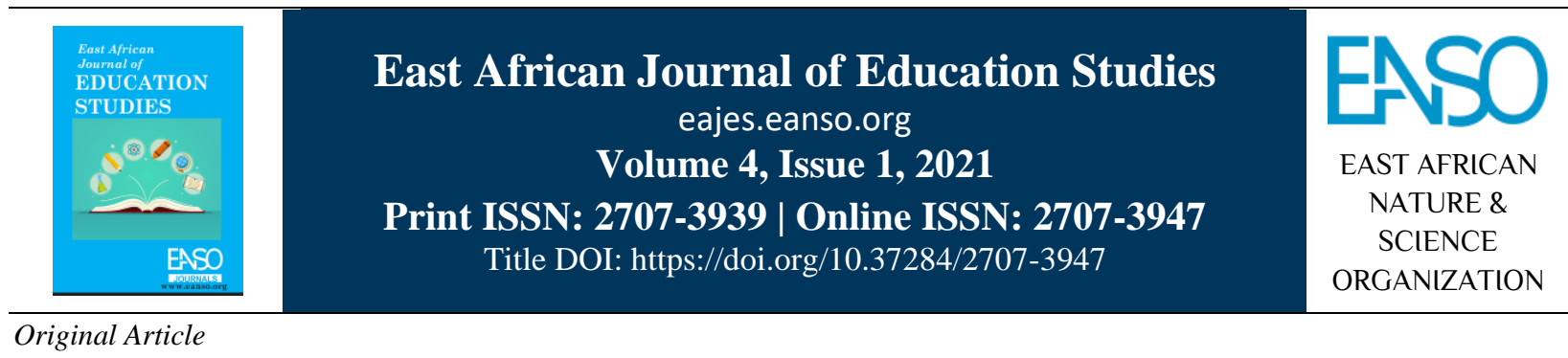

\title{
Pre-School Teacher Support and Retention of Pupils in Public ECDE Centres Kenya.
}

\author{
Caroline Wambui Mwangi ${ }^{1 *}$, Rachael Koross, $P h D^{1} \&$ Betty Cheruiyot, $P h D^{1}$ \\ ${ }^{1}$ University of Eldoret, P. O. Box 1125-30100, Eldoret, Kenya. \\ * Author for Correspondence ORCID ID: https://orcid.org/0000-0003-3730-0659; Email: carolmwangi020@gmail.com.
}

Article DOI: https://doi.org/10.37284/eajes.4.1.507

\section{Date Published: ABSTRACT}

14 December 2021 Pre-primary teachers need support from the government to ensure that they perform their instructional duties in the classroom effectively. With the devolving of Early

Keywords: Childhood Development Education from the national government to the county level, it was expected that this action would improve the standard and status of

Support, learning in these institutions. However, studies have shown that the expected Pre-Primary reforms have been done at a slow pace affecting the achievement of ECDE

Teacher, objectives. This paper looks at the kind of support that teachers are provided with

$E C D E$, by the county government and its impact on the retention of pupils in public pre-

Retention, primary schools in Wareng Sub County, Uasin Gishu County, Kenya. This study Devolution. was conducted in 83 public pre-primary schools in Wareng Sub County, Uasin Gishu County. The study applied a descriptive survey research design with the target population involving 166 pre-school teachers and five county government ECDE field officers. The research instruments involved the use of questionnaires and interview schedules. Qualitative and quantitative approaches were used in data analysis. Research results showed that all respondents agreed that there has been a significant change in public pre-primary centres because of the devolution support. Correlation statistics showed that there existed a significant positive relationship between pre-primary teachers' support and retention of pupils in public ECDE centres in Wareng Sub County, Kenya. The study recommends that additional preprimary teachers should be employed in schools with a higher learner population and terms of employment should be permanent and pensionable.

\section{APA CITATION}

Mwangi, C. W., Koross R., \& Cheruiyot B. (2021). Pre-School Teacher Support and Retention of Pupils in Public ECDE Centres Kenya. East African Journal of Education Studies, 4(1), 107-118. https://doi.org/10.37284/eajes.4.1.507.

107 | This work is licensed under a Creative Commons Attribution 4.0 International License. 


\section{CHICAGO CITATION}

Mwangi, Caroline Wambui, Rachael Koross \& Betty Cheruiyot. 2021. "Pre-School Teacher Support and Retention of Pupils in Public ECDE Centres Kenya”. East African Journal of Education Studies 4 (1), 107-118. https://doi.org/10.37284/eajes.4.1.507.

\section{HARVARD CITATION}

Mwangi, C. W., Koross R., \& Cheruiyot B. (2021) "Pre-School Teacher Support and Retention of Pupils in Public ECDE Centres Kenya”, East African Journal of Education Studies, 4(1), pp. 107-118. doi: 10.37284/eajes.4.1.507.

\section{IEEE CITATION}

C. W. Mwangi, R. Koross \& B. Cheruiyot. "Pre-School Teacher Support and Retention of Pupils in Public ECDE Centres Kenya", EAJES, vol. 4, no. 1, pp. 107-118, Dec. 2021.

\section{MLA CITATION}

Mwangi, Caroline Wambui, Rachael Koross \& Betty Cheruiyot. "Pre-School Teacher Support and Retention of Pupils in Public ECDE Centres Kenya". East African Journal of Education Studies, Vol. 4, no. 1, Dec. 2021, pp. 107-118, doi:10.37284/eajes.4.1.507.

\section{INTRODUCTION}

Pre-primary education also commonly known as early childhood development education (ECDE) is the lowest basic education structure catering for children who are aged $4-8$ years (Oyamo, 2013). The desire for early childhood education was promoted by great philosophers Quintillion, Aristotle, Plato, among others as important to children's development in the early stages of their life (Bukaliya \& Kudakwashe, 2012). Were (2014) informed that ECDE is designed to care and nurse all young children's life aspects to improve their holistic development. Early years $(4-8)$ are critical in laying the foundation for children learning since it is of great importance to all learners and therefore needs to be accessible to all (Hirst, Jewis, Sojo \& Cavanagh, 2011). Therefore, pre-primary education gives a good foundation for children learning as it aids in skills and knowledge development in addition to confidence, a sense of social responsibility and personal competence (Murunga, 2015). Hence, every child needs to access and be retained in ECDE. For pupils to be retained in schools, teachers have to be properly supported by their employers.

Teacher support in continuous professional development and also better remuneration might affect curriculum delivery in the classroom (United Nations Education Scientific and Cultural Organisation-UNESCO, 2013). However, according to research studies, ECDE teachers are looked upon and viewed of less importance than those teaching in primary schools or higher level (Armstrong, 2009; Britton \& Propper, 2015; Nduku, 2016). This affects their motivation and commitment level that is critical in ensuring that ECDE children develop an interest in learning thereby increasing retention challenges. Mureithi (2013) study in Kiambu County found out that pupils who tend to repeat classes were under instruction by untrained teachers. Those who were taught by trained teachers were adequately prepared to transit to the primary level of education. Increased incidents of repetition contributed to learners dropping out of schools since they are demotivated to learn and continue with their schooling. Poor teacher motivation to teach may affect teaching; hence pupils may miss coming to school on a daily occasion. This state of affairs motivated the researcher to investigate whether with the incoming county government, teachers have been supported as a measure of ensuring high retention in pre-schools. The main purpose of the study was to assess the influence of devolution support to ECDE teachers on the retention of preschool learners in public centres in Wareng Sub County.

\section{REVIEW OF LITERATURE}

For learning to effectively take place in schools, teachers have to be availed and supported. It is the duty of the government to ensure that teachers are availed and supported through various means in schools (Britton \& Proper, 2015). This will ensure that teachers are well satisfied with their jobs and this performs a significant role in ensuring that they conduct their instructional activities well to aid in child knowledge development and which might ultimately result in learner retention in schools in the long run (OECD, 2019). Government support to teachers may happen in various forms like; being 
paid well (remuneration) sponsored to attend training seminars and workshops and also motivated (extrinsic and intrinsic).

Baguiley (2009) informs that teacher remuneration can be categorised into either incentives or compensations. In schools, the pre-primary teachers are remunerated based on the services that they render to pupils in classrooms by county governments. The government develops a paying formula for each teacher based on the job responsibility, work experience, additional roles and education level (Barkhuizen, 2014). Aside from the government, Schlechter, Faught and Bussin (2014) indicated that schools are now discovering methods of remunerating their teachers in schools based on their instructional work targets. This means that aside from what the government is offering, there is need also for schools to have their own methods of remunerating their teachers in schools since it is not generalised but customised to their own teachers. Durai (2010) advises that institutions are under growing pressures to ensure that what teachers are paid is based on their skills, knowledge, abilities and performance of their jobs. This implies that schools should reward their teachers for the achievements they make in schools.

In South Africa, teachers indicated that nonfinancial rewards (holidays, working hours) that they required would ensure that they remained committed to their duties and have low tendencies of turnover intentions (South African Council for Educators-SACE, 2019). Teachers indicated that when they are properly supported, it increases their sense of belonging to the school, work productivity and personal connectedness with the children. Armstrong (2009) found out that teachers are regularly challenging the poor reward and communication practices that they receive from their employers. This has resulted in a mass exodus of teachers from South African schools to seek better compensations in other careers and countries (SACE, 2019).

This research focused on whether teachers employed by the county government in Kenya are satisfied with the level of financial compensation they are receiving and whether it affects learners' retention in schools. Turnover of teachers in schools results in considerable loss of service effectiveness that ends up having a negative effect on school children performance (Williams, Champion \& Hall, 2012). Efficient reward and retention practices increase teacher capacities and schools' overall performance (Shukla, 2009). Retention strategies need to be able to attract new teachers, motivate the existing ones and motivate them to stay in the teaching profession (Barkhuizen, 2014). This means that the employers (governments) have to ensure that remuneration practices are favourable as a way of retaining teachers and improving the curriculum delivery process.

In the US, Podgursky and Springer (2011) examined teacher compensation methods in K-12 public schools. They established that the compensation methods for teachers were uncoordinated and fragmented with provisions regularly determined by means that were not systematic in evaluating the overall incentives influence. They recommended that government and school managers need to reform compensation systems in all schools to ensure that they are of benefit and satisfaction to teachers. As cited by Moraa (2015) Bowen, Radhakrishna and Keyser (1994) utilised Herzberg's theory to examine the function of hygienic and motivating factors on Indian teachers' academic performance. They found out that teachers were mainly satisfied with interpersonal associations innate of being teachers and the least satisfied with the mechanism that was used to pegged their salary. They concluded that teachers' satisfaction with their work was independent of age, employment form and the number of years of being teachers.

In the UK, Britton and Propper (2015) examined the influence of labour markets on teachers' salaries. They indicated that teachers' salaries are mainly set in the way that they are flat across labour markets that are heterogeneous. This resulted in a gap between the inside (regulated) and outside labour market for instructors. They utilised a centralised wage policy for teachers to assess the influence of pay on the performance of the school. Data came from 200,000 teachers from more than 3,000 schools who taught children in schools. The results showed that teachers' pay was based on the performance of pupils in exams and that a drop in performance resulted in a drop in teachers' wages in England. 
In South Africa, Nthebe (2015) examined the influence of rewards on school principals' effectiveness. Findings revealed that rewards provided were a predictor of principals' service orientation and wellbeing. Nthebe also indicated that total rewards systems would be applicable for utilisation by other sector players like teachers as well. Makhuzeni and Barkhuizen (2015) indicated that many schools in South African were faced with the challenge of retaining competent teachers and one of the recommendations was that a reward strategy needed to be introduced to keep those teachers in schools. From their results, they discovered that the total wards strategies of teacher compensation, career development and performance management were poorly used in schools. This increased incident of teacher turnover because they were not appreciated which affected pupils learning. The teachers found it difficult to balance their individual needs with work benefits as they deemed it to be inadequate. The gap created from their study is that they looked at teacher retention, whereas this study focused on pupil retention.

In Zimbabwe, Chimanikire et al. (2007) discovered that majority of faculty members in tertiary colleges were dissatisfied with their jobs. Job dissatisfaction came as a result of poor salaries, inadequate allowances, and inaccessible credit facilities for mortgage and vehicle purchases in addition to increased workload. This means that teachers received little support from their employers hence affecting their service delivery standards. Another study by Ikenyiri and Ihua-maduenyi (2011) in Nigeria focused on instructors' evaluation of needs effectiveness in primary schools. They discovered that the enhancement of housing and transport allowance had a strong influence on teacher effectiveness in curriculum instructions in schools. Further, Olusola (2014) assessed factors inhibiting effective performance by primary school teachers in selected primary schools in Oyo State, Nigeria. Results showed factors that inhibited teacher effectiveness were; job security, illegal deductions of teachers' salaries, irregular bank charges, irregular teacher transfers, inadequate motivation of teachers and education officers' poor working relationship with teachers. This means that teachers received less support, which affected their instructional performance.
In East Africa, Nairuba (2011) assessed motivational practices' effects on teacher performance in primary schools in Jinja town, Uganda. Results showed that fringe benefits like; praise, promotion, recognition and allowance depended on funds availability and school management view on teacher work productivity. There was also a weak relationship between motivational practices and the performance of teachers in schools. The researcher concluded that teacher support factors affected the performance of teachers in schools. Still, in Uganda Masaka District, Acham et al. (2012) investigated the motivation effect on primary school teacher performance. They established the existence of a positive relationship between motivational (extrinsic and intrinsic) and teacher work performance. This means that motivation support was key to increased performance of teachers, which would ensure that learners are retained in schools.

In Kenya, Moraa (2015) examined how the school working environment affected pre-primary teachers' job satisfaction in Kisii County. It was a descriptive survey study that selected 72 teachers through a simple random sampling method. Results showed that many teachers were dissatisfied with the basic salary that they received $(61.1 \%)$, gender balance $(52.8 \%)$, non-financial benefits $(55.6 \%)$ and promotion method $(51.5 \%)$ and allowances (77.8\%). In another study within the city, Wangari and Orodho (2014) examined job satisfaction determinants and special needs teachers' retention in Nairobi County. A descriptive survey design was used. Results showed that many teachers were not satisfied with their terms and conditions for the job and had turnover intentions in the future if new opportunities came their way. When pre-primary teachers leave, learners are also likely not to come to school because teachers are not there.

Another area of teacher support is through the provision of training and continuous professional development of teachers. SEAMEO and UNESCO (2016) indicate that with changing situations in curriculum and pedagogical approaches, practising teachers require knowledge and skills to prepare them to fully implement new methods of teaching. They recommended that the nation should develop comprehensive and systematic methods of 
continuous professional development (CPD) programmes for teachers. Mupa and Tendukai (2015) said that CPD is a technique that schools utilise to make sure that teacher continuously strengthens their instructional practices throughout their career with the focus on addressing the unique needs of pupils. Through teachers' participation in CPDs, they learn how to solve problems together so that pupils' academic success can be attained. Schools utilise various programmes to offer work time and collaborative learning for teachers. When time is set for teacher training, it should be planned and implemented effectively, parents receive results about their children's outcomes, they realise the advantages to instructors and their learners far outweigh when there is an inconvenience in scheduling (Olusola, 2014).

In South Africa, a study by the Department of Education (2012) established that teachers who had been recently trained had less experience in teaching appeared to be more effective in their instructional tasks compared to those who had many years of experience. This is because the newly hired teachers had more to provide because of the knowledge and skills they had compared to those that had been teaching for long in schools. Foskett and Lumby (2002) indicated that employers might significantly contribute to their teachers CPD by supporting them to undergo those training. Therefore, the South African Department of education may need to motivate and retain teachers by offering them CPD to increase their knowledge and skills and eventually performance in their instructional duties (Schullion, 2011). Research in South Africa by Strauss (2012) found out that teachers teaching in rural schools had limited access to CPD opportunities. Barkhuizen (2014) indicated that CPD is an essential feature that attracts and retain teachers. Armstrong (2009) opined that the high turnover rate of teachers' affects classroom instructions. This means that the government needed to invest in CPD so as to ensure that teachers' number is adequate in schools.

In Malawi, Selemani-meke (2013) examined factors influencing teacher motivation in implementing what they gained after attending CPD programmes. The research discovered that low allowances given to teachers during CPD resulted in low teacher motivation to effectively implement what they learnt in classroom learning. It was recommended that CPD programmes implementers needed to increase teacher allowance as a way of motivating them to participate fully in training and which would result in the improvement of their teaching and learning activities in classrooms hence the retention of learners.

In Zimbabwe, Moyo et al. (2012) studied factors affecting the implementation of ECD programmes. They found out that teacher qualification had a significant influence on the effective implementation of ECD programmes. Their study showed that many teachers were not qualified to teach in ECD and this lacked adequate knowledge and skills in implementing the curriculum. The unqualified teachers did not have basic knowledge on pre-primary syllabus interpretation and hence they turned to formal teaching approaches, which are not allowed. Another research was conducted by Bukaliya and Kudakwashe (2012) to evaluate the advantages and challenges of the ECD programme in primary schools. Results showed that many teachers felt reassured to teach learners who had gone through pre-primary since they were already exposed to classroom activities. However, they noted that one of the challenges is that untrained teachers were hired by pre-primary schools to teach in class and that field education supervisors were not performing their jobs in ensuring that teachers teaching in pre-primary schools were competent and qualified.

In Abuja, Nigeria, Bose (2016) study looked at the degree to which instructional supervision correlated with the performance of teachers. Results showed that adequate supervision in ECD helped teachers to acquire new skills, assisted teachers with less experience to understand new pedagogical methods, which helped them to identify, categorise and instruct learners with special needs. However, the training was not provided on regular occasions.

In Kenya, Wanjiku (2013) examined the effects of teacher characteristics on pre-primary classrooms climate in Ongata Rongai. Results showed that preprimary teachers that had secondary level of education developed a better classroom environment compared to those that had primary level of education. This meant that training had a significant influence on cognitive aspects of the 
classroom environment while it did not significantly matter when it came to the social and physical development of pupils because teachers who were untrained could even utilise natural hereditary intuition in taking care of children because all teachers surveyed were female. Pupils taught by untrained teachers performed better in physical activities because their teachers compensated for their inadequate pedagogical competencies in classroom delivery by permitting pupils to be engaged more in playing activities. The gap created from this study is that it did not capture the issue of how the untrained teachers were supported by their schools to ensure learners are retained in the classroom, a focus that this study intends to undertake.

\section{MATERIALS AND METHODS}

The study was grounded on a mixed-method research methodology. A mixed methodology was utilised in all phases of this study to obtain adequate data on the influence of teacher support on the retention of pupils in public ECDE centres in Wareng Sub County. In terms of design, the study used a descriptive survey design. The study was conducted in Wareng Sub County, Kenya. It is one of the three sub-counties in Uasin Gishu County. Wareng Sub County has 83 public primary schools with pre-school centres attached to them. The study target population involved all teachers in pre-school classes (Pre-primary 1 and Pre-primary 2) in 83 public pre-school centres in Wareng Sub County and 5 county government officials (field officers) in charge of ECDE in the Sub County distributed in the five zones.

The study target population comprised 166 preschool teachers and 5 county government education field officers. The researcher used Morgan and Krejcie's (1979) table to calculate the sample size for the study. According to the table, when the target population was 166 , the corresponding sample size was 113. Therefore, the final sample size for the research consisted of 113 teachers and five county government ECDE field officers from Wareng Sub County. Research instruments are tools used in the collection of data on the phenomenon of the study (Creswell, 2014).

The study used a questionnaire, interview guide and observation checklist to gather information from the study respondents. The questionnaire was used for ECDE teachers. An interview schedule was developed for county government officers in charge of ECDE. The quantitative data was coded, entered and analysed with the help of Statistical Product and Service Solution (SPSS version 23.0). Analysis of quantitative data was through descriptive statistics; frequencies, percentages, means and standard deviation. Quantitative analysis also involved performing a Karl Pearson correlation to determine the direction and strength of the relationship between independent and dependent variables. Qualitative data from interviews were analysed using themes and sub-themes through content analysis. Analysed data presented using tables, graphs and narrations.

\section{RESULTS AND DISCUSSIONS}

The objective of the study sought education officers' and pre-primary teachers' views with regard to the kind of support that teachers are provided to ensure learners are retained in schools through the input of the county government of Uasin Gishu in Wareng Sub County public pre-primary centres. The teachers were asked to indicate the level of agreement on the extent to which they were supported by the county government of Uasin Gishu. The results are presented in Table 1 . 
East African Journal of Education Studies, Volume 4, Issue 1, 2021

Article DOI: https://doi.org/10.37284/eajes.4.1.507

Table 1: Teacher Support by County Government of Uasin Gishu

\begin{tabular}{|c|c|c|c|c|c|c|c|}
\hline Teacher support & SD & D & $\mathbf{U}$ & $\mathbf{A}$ & $\mathbf{S A}$ & $\mathbf{M}$ & SD \\
\hline $\begin{array}{l}\text { Low salaries payment affects } \\
\text { our motivation to perform duties }\end{array}$ & $\begin{array}{l}12 \\
(11.2 \%)\end{array}$ & $\begin{array}{l}16 \\
(15.0 \%)\end{array}$ & $\begin{array}{l}15 \\
(14.0 \%)\end{array}$ & $\begin{array}{l}36 \\
(33.6 \%)\end{array}$ & $\begin{array}{l}28 \\
(26.0 \%)\end{array}$ & 3.4860 & 1.3273 \\
\hline $\begin{array}{l}\text { Non employment of adequate } \\
\text { teachers affects pupil's } \\
\text { attendance in school }\end{array}$ & $\begin{array}{l}16 \\
(15.0 \%)\end{array}$ & $\begin{array}{l}10 \\
(9.3 \%)\end{array}$ & $\begin{array}{l}18 \\
(16.8 \%)\end{array}$ & $\begin{array}{l}45 \\
(42.1 \%)\end{array}$ & $\begin{array}{l}18 \\
(16.8 \%)\end{array}$ & 3.3645 & 1.2914 \\
\hline $\begin{array}{l}\text { Lack of professional identity by } \\
\text { county government affects } \\
\text { teacher morale in performing } \\
\text { their duties }\end{array}$ & $\begin{array}{l}9 \\
(8.4 \%)\end{array}$ & $\begin{array}{l}20 \\
(18.7 \%)\end{array}$ & $\begin{array}{l}18 \\
(16.8 \%)\end{array}$ & $\begin{array}{l}27 \\
(25.2 \%)\end{array}$ & $\begin{array}{l}33 \\
(30.8 \%)\end{array}$ & 3.5140 & 1.3273 \\
\hline $\begin{array}{l}\text { Inadequate opportunity for in- } \\
\text { service training affects teacher } \\
\text { pedagogical competencies and } \\
\text { knowledge advancement }\end{array}$ & $\begin{array}{l}4 \\
(3.7 \%)\end{array}$ & $\begin{array}{l}18 \\
(16.8 \%)\end{array}$ & $\begin{array}{l}16 \\
(15.0 \%)\end{array}$ & $\begin{array}{l}52 \\
(48.6 \%)\end{array}$ & $\begin{array}{l}17 \\
(15.9 \%)\end{array}$ & 3.5607 & 1.0656 \\
\hline \multirow[t]{2}{*}{$\begin{array}{l}\text { Lack of fringe benefits for } \\
\text { teachers; } \\
\text { recognition, promotion and } \\
\text { praise affect teacher delivery of } \\
\text { content }\end{array}$} & & $\begin{array}{l}16 \\
(15.0 \%)\end{array}$ & $\begin{array}{l}8 \\
(7.5 \%)\end{array}$ & $\begin{array}{l}36 \\
(33.6 \%)\end{array}$ & $\begin{array}{l}47 \\
(43.9 \%)\end{array}$ & 4.0654 & 1.0575 \\
\hline & & & & & & 3.5981 & 1.2138 \\
\hline
\end{tabular}

Key: SD - Strongly Disagree, D - Disagree, U - Undecided, A - Agree, SA - Strongly Agree, M - Mean, SD - Standard Deviation.

Results showed that $36(33.6 \%)$ of pre-primary teachers agreed and $28(26.0 \%)$ strongly agreed that the low salaries that they receive (Kshs. $10,000 /=$ as indicated by school heads interviewed) affects their morale and motivation to perform their duties. Only $16(15.0 \%)$ disagreed and $12(11.2 \%)$ strongly disagreed with the statement. This means that the low salaries that teachers receive from the county government affect their motivation as it is not commensurate to the workload and responsibilities that they have in school. The results coincide with Moraa (2015) who found out that majority of preprimary teachers in Kisii County were not satisfied with the payment package that they received from the county government. This information on teachers receiving low salaries was supported by all 5 ECDE field officers interviewed, who agreed that pre-primary teachers are not well remunerated by the Uasin Gishu County Public Service Board since they were employed. Officer No. 1 remarked that:

Teachers are not well remunerated - what they get cannot even be called a salary. They get very little money that cannot motivate them. Government should do something about that.
Similarly, Officer No. 2 mentioned the following:

Remunerations - teachers are paid very little to be called a salary

The results coincide with Oyamo (2013), where $95.2 \%$ indicated that teachers received low salaries and this affected their satisfaction as remuneration ranged from Ksh. 500-3,500/= per month before county government came in the year 2013, which was expected to increase. In addition, Wangari and Orodho (2014) established that the low salary given to did not commensurate with their teaching workload and affected their level of satisfaction in schools.

Secondly, $45(42.1 \%)$ of teachers agreed and 18 (16.8\%) strongly agreed that non-employment of adequate teachers affects pupils' attendance to school. The results showed that $58.9 \%$ of teachers agreed that existing teachers are faced with a huge workload that affects pupils' attendance and also teachers' inability to make follow up on individual pupils. Nevertheless, the officers interviewed said that some schools have two teachers employed by the county government while others have one. To 
other schools (only a few), they are yet to get teachers employed by the county government. One Officer No. 4 said that:

The county government has so far employed two teachers in every public ECDE in the county. This has been a burden to parents and the community at large.

The situation of lack of adequate teachers was experienced by Bukaliya and Kudakwashe (2012), who found out that $90.0 \%$ of schools hired unqualified ECDE teachers hence compromising the quality of learning provided in schools.

Thirdly, results showed that 27 (25.2\%) of teachers agreed and 33 (30.8\%) strongly agreed that lack of professional identity by county government affects their moral in performing duties. Only 20 (18.7\%) disagreed and 9 (8.4\%) disagreed with the statement. This means that teachers are not professionally recognised by the county government and this affects their service delivery level since they are seen as inferior compared to other county government employees whose job security is guaranteed and they are not under contract. This finding agrees with Wangari and Orodho (2014), who found out that teachers were lowlily recognised compared to other county government workers who earned comparatively higher salary perks. This means that the lack of valuing the pre-primary teachers may increase the potential of transfers to private schools that are paying off well or even switching their career professions.

Results reveal that close to half $52(48.6 \%)$ of teachers agreed and $17(15.9 \%)$ strongly agreed that inadequate opportunity for in-service training affects their pedagogical work in the classroom, which is a determinant of whether pupils can participate or not. The information was backed up by three education officers interviewed where Officer No. 1 said that:

The county government have failed in providing continuous professional development, visiting teachers in classes and finding out the challenges they face in the delivery of lessons and retraining of teachers.
This means that field officers agreed that the county government of Uasin Gishu has not done much in the field of supporting teachers in professional development. This means that the county government does not hold or sponsor pre-primary teachers for regular in-service training and workshops to increase their knowledge and skills in ECDE curriculum implementation. The results coincide with Mureithi (2013) research from Kiambu county, which showed that the number of pre-primary teachers who received training on transition was slightly lower compared to those in primary schools. Teachers who received training on transition registered higher retention rates compared to those who received little training on transition. However, two officers said that the teachers had received training from the county government. Officer No. 3 reported that:

ECDE teachers are employed by the county government. The teachers are also supported through training and classroom observation by the officers to ensure quality education is offered in ECDE centres.

The only training that they admitted pre-primary teachers was on the new CBC curriculum as noted by Officer No. 4, who said that:

The county government has trained all ECDE teachers on the previous and the new curriculum on how to develop professional records and to implement them effectively.

On the last statement, 47 (43.9\%) of pre-primary teachers strongly agreed and $36(33.6 \%)$ agreed that lack of fringe benefits for teachers like promotion, recognition, allowances and praise affected their service delivery. This means that teachers are not provided with fringe benefits and therefore have less motivated when performing their duties which may affect the retention of pupils in their classrooms in some way or another. Wangari and Orodho (2014) supported this finding, noting that additional duty allowance provided to teachers was not available despite the work they were doing to promote learning in schools. In addition, Moraa (2015) found out that pre-primary teachers were not satisfied with their conditions of employment since fringe benefits like healthcare package, housing allowance and job security were not provided to them. 
Composite data shows that $71.9 \%$ of teachers $(M=3.59, S D V=1.21)$ agreed that the support provided to them is low and to check if this level of support affected their retention of pupils. The result agrees with Wangari and Orodho (2014) research that found out that $54.7 \%$ of teachers reported that the support they were receiving was inadequate.
This means that teacher support is critical, but the situation on the ground in many areas of the country point to a different picture.

A correlation analysis was performed and the results are presented in Table 2.

Table 2: Effect of Teacher Support on Retention of Pupils

\begin{tabular}{llll}
\hline & & Teacher Support & Retention of Pupils \\
\hline Teacher Support & Pearson Correlation & 1 & $.236^{*}$ \\
& Sig. (2-tailed) & & .014 \\
& $\mathrm{~N}$ & 107 & 107 \\
\hline Retention of Pupils & Pearson Correlation & $.236^{*}$ & 1 \\
& Sig. (2-tailed) & .014 & \\
& $\mathrm{~N}$ & 107 & 107 \\
\hline
\end{tabular}

*. Correlation is significant at the 0.05 level (2-tailed).

Results showed that there exists a significant positive effect $(r=0.236, p=0.014)$ between teacher support and retention of pupils. The correlation values are positively weak $(r<0.5)$, which means that teachers have not been offered much support by the county government to ensure they perform their duties well hence the retention of students. However, the correlation statistics suggest that if more support is provided to teachers by the county government, the retention of learners will increase significantly and vice versa is true. This is reinforced by Britton and Propper (2015) who indicated that teacher pay is significant to improved school outcomes, which include retention of teachers and pupils. They found out that in the UK, regulated pay, which was outside the labour market practices affected learners' performance in schools. The information on inadequate support that preprimary teachers received was supported by officer No. 5 who indicated that:

Also, teachers are regularly in school because they are paid by the county government. Also, teachers are trained and empowered by being supported, thus providing effective quality education in class and most parents are not taking their children to private schools.

This means that the support that the county government provides to teachers is a critical ingredient towards higher retention of pre-primary learners in public schools in Wareng Sub County, Kenya.

\section{CONCLUSIONS}

The research results showed that the county government of Uasin Gishu had at least employed two teachers in the majority of schools on a contract basis. However, reports showed that not all schools' pre-primary teachers had been employed by the county government. The teachers indicated that the jobs offered by the county government do not guarantee their security to remain there if an opportunity arises because the pay is low and there are no other incentives attached to it apart from the salary of Ksh. 10,000/= and NHIF payments. Results also showed that despite the initial training that teachers underwent on a competency-based curriculum, the training and workshops are rare. The study found out that teachers were inadequately supported and this affected their service delivery, motivations and even capacity to implement classrooms responsibilities well. This goes against the principles of constructivism theory which says that learning interactions should be there between teachers, learners and the school environment to promote learning. In a situation where teachers are not well supported, the acquisition of knowledge and skills becomes impossible. The ECDE officers interviewed suggested that the support that the county government can provide to ECDE teachers is to employ them on permanent and pensionable 
terms like other county government workers employed by County Public Service Board. Computed correlation statistics showed that there existed a significant positive effect $(\mathrm{p}<0.05)$ between pre-primary teacher support and retention of public pre-primary teachers in public pre-primary schools in Wareng Sub County, Kenya. Teacher support was a major area that had contributed a lot to the retention of learners in ECDE. This is because the parents enrolled their children in school without struggling to pay fees to meet the teachers' salaries. The teachers are also motivated and perform their duties effectively, ensuring that children acquire education.

\section{RECOMMENDATIONS}

In improving teacher support, there is a need for the county government to ensure that teacher: pupil ratio in public pre-primary schools is standardised. For teachers who are on contract terms, there is a need for the county government of Uasin Gishu to confirm them as permanent and pensionable to guarantee their job security and improve their motivation. The government also need to fund ECDE teachers on regular training one CBC curriculum implementation through attendance of workshops and seminars aimed at increasing their pedagogical competencies.

\section{REFERENCES}

Acham, H., Kikafunda, J., Malde, M., OldewageTheron, W., \& Egal, A. (2012). Breakfast, midday meals and academic achievement in rural primary schools in Uganda: implications for education and school health policy. Food \& nutrition research, 56(1) 11217.

Armstrong, A. (2009). Teacher pay in South Africa: How attractive is the teaching profession? Stellenbosch Economic Working Papers: Stellenbosch University.

Baguiley, P. (2009). Performance management (7th Ed.). London: Cox and Wyman.

Barkhuizen, N. (2014). Exploring the importance of rewards as a talent management tool for Generation Y employees. Mediterranean Journal of Social Sciences, 5(27), 1100.
Bose, E. O. (2016). Influence of early childhood instructional supervision on caregivers' effectiveness in Federal Capital Territory Centers, Abuja Nigeria. International Journal for Cross-Disciplinary Subjects in Education, 7(1) 2682-2692.

Bowen, C. F., Radhakrishna, R.B., \& Keyser, R. (1994). Job satisfaction and commitment of 4-H agents. Journal of Extension, 32 (1) 66-71.

Britton, J., \& Propper, C. (2015). Teachers pay and school productivity: Exploiting wage regulation. Journal of Public Economics, 133, 75 - 89.

Bukaliya, R. \& Kudakwashe, A.M. (2012). Assessing the benefits and challenges of the introduction of early childhood development education to the infant grade in the Zimbabwe education system. Journal of Educational and Instructional Studies in The World, 2(4) 226235.

Chimanikire, P., Mut, E., Gadzirayi, C. T., Muzondo, N., \& Mut, B. (2007). Factors affecting job satisfaction among academic professionals in tertiary institutions in Zimbabwe. African Journal of Business Management, 1(6).

Creswell, J. W. (2014). Research design: Qualitative, quantitative and mixed method approaches (4th Ed.). Thousand Oaks, CA: Sage Publications.

Durai, P. (2010). Human resource management. New Delhi: Dorling Kindersley (India) Pvt. Ltd.

Foskett, N., \& Lumby, J. (2002). Leading and managing education: International dimension. London: Sage Publication.

Hirst, M., Jewis, W., Sojo, R., \& Cavanagh, S. (2011). Transition to Primary: A Review of the Literature.

Ikenyiri, E., \& Maduenyi, R. I. (2012). Teachers Assessment of Needs Satisfiers as Motivation for Effectiveness in Rivers State Primary Schools in Nigeria. Mediterranean Journal of Social Sciences, 3(4) 69-69. 
Jaluo, M. W. (2015). Devolving Early Childhood Development Education in Kenya: Policy Challenges and Opportunities.

Justine, N. (2011). Motivational Practices and Teachers' Performance in Jinja Municipality Secondary Schools, Jinja District, Uganda. Online Submission.

Krejcie, R. V., \& Morgan, D. W. (1970). Determining sample size for research activities. Educational and psychological measurement, 30(3) 607-610.

Makhuzeni, B., \& Barkhuizen, E. N. (2015). The effect of a total rewards strategy on school teachers' retention. SA Journal of Human Resource Management, 13(1) 1-10.

Mosomi, M. M. (2015). Job Environment and Satisfaction Among Pre-School Teachers in Kisii County, Kenya. Unpublished Med thesis, Kenyatta University, Nairobi.

Moyo, J., Wadesango, N., \& Kurebwa, M. (2012). Factors that affect the implementation of early childhood development programmes in Zimbabwe. Studies of Tribes and Tribals, 10(2) 141-149.

Mukiti, A. N. (2016). Institutional based factors influencing the implementation of early childhood development programmes in public early childhood centres in Matungulu subcounty, Kenya (Doctoral dissertation).

Mupa, P., \& Chinooneka, T. I. (2015). Factors Contributing to Ineffective Teaching and Learning in Primary Schools: Why Are Schools in Decadence? Journal of Education and Practice, 6(19) 125-132.

Mureithi, J. W. (2013). Factors influencing learners' transition from Preschool to Primary school. A case of public schools in Thika-West District, Kiambu County-Kenya (Doctoral dissertation, University of Nairobi).

Nthebe, K. J. (2015). The relationship between remuneration, wellbeing, service quality and the intention to quit of school principals in the North-West Province. Master's thesis, NorthWest University, Mafikeng.
Olusola, F. J. (2014). Evaluation of factors inhibiting effective performance of primary school teachers in some selected local government education areas in Oyo State, Nigeria. African Journal for the Psychological Studies of Social Issues, 17 (1) 1-15.

Organisation for Economic Cooperation and Development (2019). Education at a glance 2018: OECD Indicators. Paris: OECD iLibrary.

Oyamo, J. M. (2013). Factors influencing participation of children in the early childhood development education programme: A Case of Bungoma South Sub County, Bungoma CountyKenya. MAPPM Project, University of Nairobi.

Podgursky, M. \& Springer, M. (2011). Teacher compensation systems in the United States K-12 public school system. National Tax Journal, 64(1) 165-192.

Schlechter, A., Faught, C., \& Bussin, M. (2014). Total rewards: A study of artisan attraction and retention within a sought African context. $S A$ Journal of Human Resource Management, 12(1) 1-13.

Schullion, H. (2011). Global talent management. New York: Taylor \& Francis.

SEAMEO \& UNESCO (2016). Southeast Asian guidelines for early childhood development and management teacher. Published by SEAMEO Secretariat and UNESCO Bangkok Office.

Selemani-Meke, E. (2013). Teacher motivation and implementation of continuing professional development programmes in Malawi. Anthropologist, 15(1) 107-115.

Shukla, R. (2009). Talent management: Process of developing and integrating skilled workers. Global India Publications.

South Africa Department of Basic Education (2012). Guidelines relating to planning for public school infrastructure. Pretoria: Department of Basic Education.

South African Council for Educators [SACE] (2019). Annual report 2019/2020. Pretoria, SACE. 
Strauss, M. (2012). Exploring the factors for attracting and retaining teachers to rural areas. Unpublished Master's dissertation. Pretoria: Faculty of Economic and Management Sciences, University of Pretoria.

UNESCO. (2013). Expanding equitable early childhood care and education is an urgent need. Education for All Global Monitoring Report, Policy Paper 3. Paris: EFA report.

Wangari, N. S. \& Orodho, J.A. (2014). Determinants of job satisfaction and retention of special education teachers in primary schools in Nairobi County, Kenya. IOSR Journal of Humanities and Social Science, 19(6) 126-133.

Wanjiku, T. R. (2013). Effects of teacher characteristics on the classroom climate of preschools in Ongata Rongai Zone, Kajiado North Sub County, Kenya. MED Project, University of Nairobi.

Were P. O. (2014). Effects of teaching and learning resources on pre-school learners transition to class one: A case study of Rachuonyo South Sub County. Journal of Education and Practice, 5(34) 154-160.

Williams, C., Champion, T., \& Hall, I. (2012). $M G M T\left(2^{\text {nd }}\right.$ Ed.). USA: Nelson Education Ltd. 